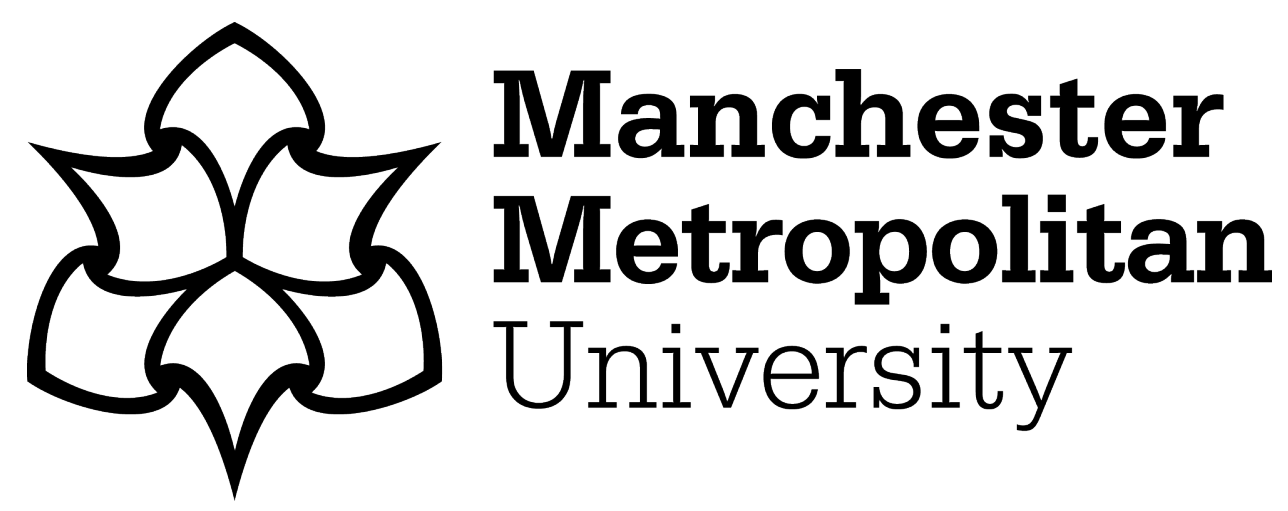

Rowley, JE ORCID logoORCID: https://orcid.org/0000-0003-3437-6914 and Sbaffi, L (2018) Academics' attitudes towards peer review of scholarly journals and the effect of role and discipline. Journal of Information Science, 44 (5). pp. 644-657. ISSN 0165-5515

Downloaded from: https://e-space.mmu.ac.uk/619747/

Version: Accepted Version

Publisher: SAGE Publications

DOI: https://doi.org/10.1177/0165551517740821

Please cite the published version 


\title{
Academics' attitudes towards peer review in scholarly journals and the effect of role and discipline.
}

\begin{abstract}
This research contributes to the knowledge on academics' attitudes towards peer review, through an international and inter-disciplinary survey of academics, which profiles academics' views on the value of peer review, its benefits and the prevalence of unethical practices. Generally, academics regarded peer review as beneficial to improving their article, and felt that peer review contributed significantly to the effectiveness of scholarly communication. Academics agreed that peer review could improve the readability and quality of the published paper, as well as check for accuracy, appropriate methodology, novelty, and relevance to the journal. There are significant differences in the views of respondents on the basis of role, with those involved as reviewers and editors being less positive about peer review than authors. In addition, there is evidence of some disciplinary differences in views on the benefits of peer review.
\end{abstract}

Keywords: peer review; scholarly communication; researchers

\section{Introduction}

Effective scholarly communication is essential to the development, dissemination and impact of research outcomes in all disciplines and countries. Peer review is the main mechanism through which potential research outputs are evaluated and enhanced. According to Ware [1, p.4], 'Peer review is the process of subjecting an author's scholarly manuscript to the scrutiny of other who are experts in the same field, prior to publication in a journal'. Also known as pre-publication peer review, the process is seen to have two important goals: ensuring that only high quality research is published (either by rejecting or improving sub-standard manuscripts); and, ensuring the dissemination and availability of research findings to interested stakeholders, including other researchers, practitioners, policy makers, and the general public [2].

The contributions of academics, in their roles as authors, reviewers and editors, are key to the peer review process, and therefore it is important to understand their attitudes towards the purpose and effectiveness of the peer review. This research will seek to profile and develop insights into researchers' engagement with peer review in the context of academic journal article publishing. Such a study is particularly timely as scholarly communication practices are in the midst of a paradigmatic change, initiated with the advent of the internet, electronic journals, social media and other communication channels, and escalated through the increasing adoption of open access publishing. According to Nicholas et al. [3] peer review contributes to reducing the complexity of 'today's disintermediated, overly abundant scholarly information environment' (p.15). Further, recent studies on scholarly communication in general [e.g. 4,5,6] and, on open access publishing, more specifically [e.g. 7] confirm that rigorous peer review is a key consideration in researchers' choice of journal for the publication of their research, and 
is associated with journal quality and impact. In particular, in acknowledgement of the importance of peer review there have been three major surveys on this topic in recent years $[1,3,4]$, and two other key qualitative studies which have gathered the views, variously, of editors and reviewers on peer review [2,8]. On the other hand, there is a growing body of evidence on the limitations of peer review. For example, Siler et al. [9] found that of the articles in their dataset of articles submitted to elite medical journals, a number of desk rejected articles were eventually accepted by another journal, and ultimately achieved very high citation rates, whilst Lee et al. [10] and Zhao, Chi and Van den Heuvel [11] explore the nature of bias in peer review. However, none of these studies have analysed differences in views between those with different roles, and levels of experience with peer review, and nor have they considered the extent to which discipline might impact on views.

This research, then, aims to contribute to knowledge regarding academics' attitudes to peer review, and further to investigate whether there are any differences in attitudes based on roles (author, reviewer, editor) and discipline. More specifically, the objectives of this research are to:

1. Profile academics' views on: (a) the value of peer review; (b) the benefits that accrue from peer review (c) the ethics of peer review.

2. Investigate any differences in views on value, benefits and ethics, relating to peer review, between authors, reviewers and editors.

3. Investigate any differences in views on value, benefits and ethics, relating to peer review, on the basis of discipline.

Next, a literature review summarises prior literature on peer review, with a focus on the importance of peer review to scholarly communication and academics engagement with and attitudes towards the peer review process. Then, the details of the survey drawing on the international and inter-disciplinary community of authors, editors and peer reviewers for Taylor \& Francis journals is outlined and evaluated. Next, findings are reported and discussed. Finally, conclusions and recommendations for future research and practice and policy are offered.

\section{Literature Review}

Appendix 1 summarises the key characteristics of the main studies that have investigated aspects of peer review. Amongst these studies are three large-scale, global studies of the views of academics on peer review. The first of these studies was conducted by Ware [1] in 2008, and in the rapidly changing world of scholarly communication, may now be a little dated. Nevertheless, it was a large-scale international study with 3040 academics as respondents. They investigated experience, and preferences with type of peer review - with single blind being the most experienced model and double blind being the preferred model. $85 \%$ of respondents believed that peer review greatly helped scientific communication; and, $64 \%$ were 
satisfied with the peer review process, and 90\% agreed that peer review had improved their own last published paper. Most frequently cited improvements were: suggestions on presentation, and language or readability. In terms of their motivations for review, contributing to the academic community was ranked most highly (91\%), followed by enjoying being able to improve the paper (78\%) and seeing new work ahead of publication (69\%). Some questions were directed specifically at editors; these related to the use of online manuscript submission and management systems (used by about $75 \%$ of editors), their workload (typically 50 a year) and acceptance rate (typically 50\%).

Next, in 2009, Mulligan et al. [4] conducted an international online survey of researchers. Their questionnaire had three main sections collecting data respectively from the researcher (as author, reader or reviewer), author or reviewer perspective, but there was no overlap between the questions posed to these three groups. They also conducted some analysis by subject discipline, in relation to specific questions. Researchers were asked about satisfaction levels, importance and sustainability, and purpose of peer review as well as the effectiveness of different types of peer review. Authors were asked how their article had been improved by peer review, and speed. Reviewers were asked about their motivations and prompted to offer suggestions for improvements. They found that the peer review process was highly regarded, and seen to be essential for scholarly communication. $90 \%$ believed that peer review had improved their last paper. Double-blind review was the preferred model, but whilst peer review should identify fraud, it could not always do so.

Nicholas et al. [3] and Jamali et al. [12] report on an international study of 4000 academic researchers that focussed on how trustworthiness is determined in the digital environment in the context of scholarly reading, citing and publishing. Since peer review was found to be the central pillar of trust, their findings centred on the role of peer review. Nicholas et al. [3] suggest that peer review was seen to be 'a familiar, reliable and traditional practice' (p.16). Importantly, researchers want to be published in journals with robust peer review mechanisms, and, also, they prefer to cite peer-reviewed articles. They also agreed that peer review led to an increase in the quality of an article. On the other hand, academics acknowledged that there were problems with peer review, particularly with regard to slowness, hands-off editors, lighttouch peer review, and the variable quality of reviews. In addition, there was some evidence that younger academics (under 30) were less confident that peer-reviewed journals were the most trustworthy source, than older academics. Jamali et al. [12] focussed on the geographical differences in trust in reading, citing and publishing activities, and found that scholars from high Human Development Index (HDI) countries (e.g. USA and UK) are less discriminatory than authors from developing countries in their citation practices, although they regard it as important that the source is peer-reviewed. They are also more negative towards the use of repositories and social media for publishing, and doubt their potential to reach a wider audience.

There have also been some important qualitative studies, which focus on the views of reviewers on peer review. Zaharie and Osoian [8] conducted semi-structured interviews with 42 journal referees in the natural and social sciences in Romania. Their focus was on the motivation to 
review. They reported two interesting models. The first identified two distinct motivation frames that can be adopted by reviewers: member of the scientific community focussed on the groups, and prospective member of the scientific community focussed on self-achievement. Their second model captured the different benefits and costs associated with reviewing. Amongst incentives to review are: guard quality standards, screen publication, improved manuscripts, as well as relationship with the editor, career boost (e.g. professional development, privilege when submitting), and financial rewards. Review costs include time, low quality papers, and editor/author disregards the review suggestions. Lipworth et al. [2] also conducted a qualitative study, through interviews with 35 editors and reviewers in biomedicine in the UK, USA and Australia. They found that reviewers and editors were aware of a number of social and subjective dimensions (e.g. bias, and conflicts of interest, prejudice, authority and intuition), but rather than viewing these negatively, participants felt that they made a positive contribution to the peer review process. Lipworth et al. [2] concluded that the social and subjective dimensions of peer review should be made more explicit, accommodated, and even encouraged and used to enrich the review process.

There is also a group of studies that specifically focus on bias and other ethical dimensions of peer review. Lee et al. [10] defined bias in peer review as the violation of impartiality in the evaluation of a submission, and impartiality as the ability for any reviewer to interpret and apply evaluative criteria in the same way in the assessment of a submission. They propose a number of types of bias, associated, respectively, with author characteristics (including gender, prestige, nationality and affiliation), reviewer characteristics, and content. Zhao et al. [11] suggested that reviewers often have multiple biases when conducting a review, and seek to integrate these multiple biases into two groups associated with their static profiles and dynamic behavioural context, and Zaharie and Osoian [8] identified two different types of motivation frames, which align respectively with the reviewers' self-interest and their contribution to the scientific community. Taking different tacks, Garcia et al. [13] suggested that the use of associate editors can impact on bias and its effects in peer review and Nobarany and Booth [14] explored the anonymity policies of journals, and considered how the disclosure and concealment of identities can best be managed in the peer review process. Interestingly and importantly, studies that explore ethics in peer review, tend to problematize the peer review process, yet despite this, as many prior studies have confirmed, and Nicholas et al. [3] declare peer review is still king in the digital age.

\section{Summary and Contribution}

In acknowledgement of the importance of peer review, there have been three major surveys on this topic in recent years, which have gathered the views, variously, of editors and reviewers on peer review, and some specific studies on the notion of bias in peer review. These studies affirm the persistence of the importance and value of peer review in the digital age, but note its limitations and challenges, including issues associated with the ethics of, or bias in, peer review. However, none of these studies have analysed differences in views between those with different roles, and levels of experience with peer review, and in respect of discipline, only Mulligan et al. [4] have considered, to a limited extent, the impact of discipline on attitudes 
towards peer review. This research, then, seeks to ascertain whether findings from previous studies regarding the value, benefits and ethical dimensions of peer review still stand, and to extend research in this area by investigating the any differences in views on the basis of role (author, reviewer, editor or discipline).

\section{Methodology}

\subsection{Process}

In 2015, Taylor \& Francis carried out a worldwide online survey to gather authors' views on peer review (http://authorservices.taylorandfrancis.com/peer-review-global-view/). The survey was designed to gain insights on a number of aspects of peer review. The 'Peer review in 2015: a global view' survey covered five topics: the purpose of peer review, ethics in peer review, the process of peer review, and different peer review models, with 53 closed questions, many of which had a number of Likert-style statements. For example, Q6 on the Purpose of peer review asks 'In your opinion, how common do you think the following situations are in the peer review process?'. This is followed by descriptions of seven different scenarios to which respondents are requested to allocate a number between 1 and 10, where, 10=extremely common, and $1=$ extremely rare. Respondents also provided demographic information, including whether their experience of peer review related only to their role as an author, or whether they were involved as both author and reviewer, or as author, reviewer and editor. The questionnaire was piloted internally with Taylor \& Francis staff to ensure accuracy, clarity and questionnaire logic, and externally with a small group of academics. In addition, e-mails providing access to the survey were distributed in small batches to provide the opportunity to address any minor technical problems with world-wide access to the survey. This dataset was mined for interesting insights, leading to a focus in the present analysis on six main questions, which include 31 ten-point Likert-scale.

Adopting a survey approach has facilitated the gathering of data across countries and disciplines and generated a significant dataset that provides evidence that not only has value for policy development for Taylor \& Francis, but also offers some indicators of more general interest.

\subsection{Participants}

The survey was sent during Spring 2015 via email to 86,487 authors who published with Taylor $\&$ Francis or Routledge in 2013. By the end of the data collection phase, 7,875 filled questionnaires were completed, providing a response rate of $9.1 \%$. Of the total respondents, $58.8 \%$ (4637) came from Humanities and Social Sciences (HSS) disciplines and the remaining $41.1 \%$ (3238) came from Scientific, Technical and Medical (STM) disciplines. The survey targeted three key groups: authors $(15.8 \%, 1242$ respondents), people who are both authors and reviewers $(63.8 \%, 5023$ respondents $)$, and people who are authors, reviewers and have editorial duties $(20.4 \%, 1610$ respondents). The nature of the contact database also affected the 
geographical spread of respondents. $34.9 \%$ of the respondents are from the United States and Canada, 28.3\% from Europe, 21.4\% from Asia and Australasia and 4.7\% from Africa and South America, whilst $10.7 \%$ of respondents did not specify their provenance.

\subsection{Data analysis}

Data were entered into IBM SPSS Statistics 23. The dataset was initially inspected for errors and out-of-range values in each variable. The confidence interval (at a 95\% confidence level) for any one question is 1.18 , suggesting that for all questions we can be $95 \%$ that the true percentage of the entire population who would give that response would fall within $+/-1.18 \%$ of the percentage of the sample giving that response. Descriptive statistics and means and standard deviations were calculated for each of the statements. Subsequently, one-way between-groups ANOVA with post-hoc tests were carried out to compare mean scores on role (Author; Author/Reviewer; Author/Reviewer/Editor). This study focusses on reporting the results from the ANOVA with respect to the role of the respondent. Independent samples ttests were also performed on discipline, but, in the interests of readability and space, only the outcomes of these tests are reported. For example, whether the difference in attitudes between academics in STM and HSS disciplines are significant at the 0.05 level is reported, and which of the two groups has scored the highest mean value, but not individual means, standard deviations, effect size and t values.

\section{Findings}

\subsection{Introduction}

This section reports on the findings from the analysis of the data. Most of the tables report responses for the whole sample, as well as providing a comparison of the differences between respondents between the categories of: authors (Author), authors and reviewers (Reviewer), and authors, reviewers and editors (Editor), and indicating whether there are any significant differences on the basis of discipline. With regard to the categories Author, Reviewer and Editor, it is likely that there is some alignment between these categories and the level of academic seniority of the respondent, but this can not be assumed, so we do not develop this aspect of the discussion further.

\subsection{Academics' Views on the Value of Peer Review}

Table 1 summarises responses to three questions that focus on the overall value that academics place on peer review. Overall, academics regard peer review to be beneficial in improving their article (Q1, mean 7.40). They also agree that scholarly communication is greatly helped by peer review (Q2a, mean 7.71) and that the peer review process means that researchers can have confidence in the academic rigour of published articles (Q2b, mean 7.16). In addition, there are no differences arising on the basis of discipline. However, in line with responses to many of the other questions in the survey, which are discussed later, there is a significant difference 
between the responses from the three groups, to two of the questions. In particular, respondents who have only been involved as authors are more positive than those who also act as reviewers and editors. Indeed, it would appear that those who have had greater experience of the peer review process are less confident of its value; this constituency has the privilege of insights into the processing of greater numbers of articles through per review than do those academics who are only authors.

\subsection{Academics'Views on the Benefits of Peer Review}

Table 2 elaborates further on respondents' views on the specific purpose and benefits objectives of peer review. The responses relate to the extent to which academics feel that peer review is currently achieving the specified objectives. Academics are most confident that peer review can: improve the quality of the published paper $(\mathrm{Q} 4 \mathrm{~b}$, mean 7.72$)$; check for an appropriate and robust methodology (Q4h, mean 7.44); determine whether the article is relevant to the journal's aims and scope (Q4k, mean 7.44); suggest changes to improve the readability of the article (Q4i, mean 7.39); make a judgement about the novelty of the manuscript (Q4c, mean 7.38); and, determine the importance of the findings (Q4e, mean 7.34). There is also some consensus on the ability of peer review to select the best manuscript for the journal (Q4d, mean 6.91)and to provide feedback in all circumstances (Q41, mean 6.67). Respondents are less convinced that peer review: refine the translation (Q5d, mean 5.23); carry out sub-editing (Q5b, mean 5.49); detect plagiarism (Q4a, mean 5.96); and, detect academic fraud (Q4f, mean 5.91).

Interestingly, this is the part of the dataset where there is the greatest evidence of disciplinary differences. Not surprisingly, most of the questions with the higher means showed no disciplinary differences, but there were disciplinary differences on responses with higher means in the areas of: novelty judgement (Q4c), checking factual accuracy (Q4g), improving readability (Q4i) and highlighting omissions (Q4j). In addition, there were disciplinary differences on a number of other statements. Arguably, the most significant of these relate to detecting plagiarism (Q4a) and, detecting academic fraud (Q4f). In addition, opinions vary depending on the role experience of respondents, with in the case of benefits of peer review, authors are in every instance more positive than reviewers, and reviewers are in every instance more positive than editors, although these differences are mostly only significant in the authorreviewer comparison.

In conclusion, it is evident that whilst in many respects there is a consensus on the purpose of peer review and the extent to which it is delivering benefits to scholarly communication, there are some variations in practices, and perspectives between disciplines, and, on the basis of the experience of the respondents with the peer review process.

\subsection{Academics'views on the ethics of peer review}

Table 3 summarises respondents' views on a variety of ethical aspects associated with the peer review process. The first three questions in Table 3 (Q6a, Q6b and Q6c) focus on whether 
respondents suspect bias in the review process as a result of gender, geography or seniority. In terms of gender, there was a consensus that it was relatively rare for authors of one gender (either male or female) to be more likely to be accepted for publication than authors of the other gender (Q6a, mean 3.37), although authors (50\% males; 50\% females) were a little more inclined to think that this was a possibility more than reviewers (58.8\% males; $41.2 \%$ females) and editors (65.6\% males; $34.4 \%$ females). There was a much stronger view that regions might impact the likelihood of acceptance (Q6b, mean 6.16) and, contrary to the case with gender and seniority, editors were more likely to see this as common than reviewers or authors. Seniority was also regarded as a factor that might influence acceptance relatively frequently (Q6c, mean 7.05), with editors viewing this as less common than did reviewers and authors. The responses to all three questions showed disciplinary differences, suggested that respondents for STM and those from HSS had different views regarding the frequency of potential inequalities in the peer review process.

The next four questions in Table 3 (Q6d, Q6e, Q6f and Q6g) focus more directly on respondents' views on fraudulent reviewing practices, viz, delaying a review, borrowing ideas, reciprocal support, and using false identities. Responses to the first three of these questions suggested that there was a general view that all three of these could be moderately common practice. Respondents did suspect that reviewers sometimes delayed assessment to increase the likelihood of their own research being published first (Q6d, mean 5.07), and took ideas from papers they were reviewing and used them in their own research (Q6e, mean 4.96). They also thought that, on occasions, reviewers would give unduly positive reviews to authors they know in a reciprocal arrangement for similarly positive reviews for their own work (Q6f, mean 5.42). On the other hand, there was very little support for the idea that reviewer might conduct reviews under false identities (Q6g, mean 2.75). Again, disciplinary differences were in evidence, as well as some differences between authors, reviewers and editors.

Finally, Table 4 investigates the centrality of the model of peer review, by presenting insights into respondents' views on the extent to which they regard four different types of peer review to be capable of preventing one type of unethical practice, giving overly positive reviews to authors they know in order to guarantee that their own work is treated favourably. This table suggests that respondents place their confidence in double blind peer review (where the identity of both the author and the reviewer are confidential) (Q10b, mean 6.87). Their least favoured option is single blind peer review (where the reviewer is not known to the authors, but the author is known to the reviewer) (Q10a, mean 3.79). They are relatively neutral regarding open peer review (where both the author's and the reviewers' names are known to each other), (Q10c, mean 4.21), open and published peer review (where both the author's and the reviewers' names are known to each other and the reviewers' signed reports are openly published alongside the paper) (Q10d, mean 4.97), and post-publication peer review (where online readers comment on, or rate the paper following publication (Q10e, mean 4.87).

Other data from the survey suggests that double blind review is the model of peer review with which respondents are most at ease, and that their level of comfort with other methods is much lower, so that many of them may not be able to comment with any authority on the other 
methods (mean values close to 5, Table 5). On the other hand, it is interesting to note that for all types of review, other than open review, authors are more positive regarding its capabilities than reviewers, and reviewers are more positive than editors. This difference is significant for all statements for authors compared with reviewers, but only for double blind review for reviewers compared with editors. Furthermore, although on double blind review there are no disciplinary differences, these exist in the responses to all of the other types of peer review. 
Table 1. Overall value of peer review

\begin{tabular}{|c|c|c|c|c|c|c|c|c|c|c|c|c|c|}
\hline \multirow[t]{2}{*}{ Statement } & \multicolumn{2}{|c|}{$\begin{array}{l}\text { Overall } \\
\text { survey } \\
\text { results } \\
\end{array}$} & \multicolumn{2}{|c|}{ Author } & \multicolumn{2}{|c|}{ Reviewer } & \multicolumn{2}{|c|}{ Editor } & \multicolumn{3}{|c|}{$A N O V A$} & \multirow{2}{*}{$\begin{array}{c}\text { Discipline } \\
\text { Differences }\end{array}$} & \multirow[t]{2}{*}{ Scale } \\
\hline & Mean & $\mathrm{sd}$ & Mean & $\mathrm{sd}$ & Mean & $\mathrm{Sd}$ & Mean & $\mathrm{Sd}$ & $F$ & $p$ & $\begin{array}{l}\text { Effect } \\
\text { size }\end{array}$ & & \\
\hline $\begin{array}{l}\text { Q1. As an author, please } \\
\text { rate how beneficial the } \\
\text { peer review process was } \\
\text { to improving your most } \\
\text { recently published article }\end{array}$ & 7.40 & 2.06 & $7.59^{1,2}$ & 2.05 & 7.41 & 2.02 & 7.27 & 2.18 & 8.115 & $<0.001$ & 0.002 & $N O$ & $\begin{array}{c}1=\text { not at all } \\
\text { beneficial } \\
10=\text { very } \\
\text { beneficial }\end{array}$ \\
\hline $\begin{array}{l}\text { Q2a. Scholarly } \\
\text { communication is greatly } \\
\text { helped by peer review of } \\
\text { published papers }\end{array}$ & 7.71 & 1.96 & 7.74 & 1.92 & 7.70 & 1.95 & 7.79 & 2.02 & - & - & - & $N O$ & $1=$ strongly \\
\hline $\begin{array}{l}\text { Q2b. Researchers can } \\
\text { have confidence in the } \\
\text { academic rigour of } \\
\text { published articles } \\
\text { because of the peer } \\
\text { review process }\end{array}$ & 7.16 & 2.13 & $7.56^{4}$ & 2.05 & 7.11 & 2.12 & 6.95 & 2.21 & 30.478 & $<0.001$ & 0.01 & $N O$ & $\begin{array}{c}\begin{array}{c}\text { disagree } \\
10=\text { strongly } \\
\text { agree }\end{array}\end{array}$ \\
\hline
\end{tabular}

Note: empty cells (-) indicate that no significant difference has been detected.

${ }^{1}$ significant difference between: Author and Reviewer

${ }^{2}$ significant difference between: Author and Editor

${ }^{3}$ significant difference between: Reviewer and Editor

${ }^{4}$ significant difference between: All groups 
Table 2. Benefits of peer review

\begin{tabular}{|c|c|c|c|c|c|c|c|c|c|c|c|c|c|}
\hline \multirow{2}{*}{ Statement } & \multicolumn{2}{|c|}{$\begin{array}{c}\text { Overall } \\
\text { survey } \\
\text { results } \\
\end{array}$} & \multicolumn{2}{|c|}{ Author } & \multicolumn{2}{|c|}{ Reviewer } & \multicolumn{2}{|c|}{ Editor } & \multicolumn{3}{|c|}{$A N O V A$} & \multirow{2}{*}{$\begin{array}{c}\text { Discipline } \\
\text { Differences }\end{array}$} & \multirow{2}{*}{ Scale } \\
\hline & Mean & $\mathrm{sd}$ & Mean & $\mathrm{sd}$ & Mean & $\mathrm{sd}$ & Mean & $\mathrm{Sd}$ & $F$ & $p$ & $\begin{array}{l}\text { Effect } \\
\text { size }\end{array}$ & & \\
\hline $\begin{array}{l}\text { Q4a. Peer review can detect } \\
\text { plagiarism }\end{array}$ & 5.96 & 2.52 & $6.79^{1,2}$ & 2.38 & 5.84 & 2.52 & 5.71 & 2.51 & 81.068 & $<0.001$ & 0.02 & $\begin{array}{c}Y E S \\
(H S S<S T M)\end{array}$ & \multirow{11}{*}{$\begin{array}{c}1=\text { strongly } \\
\text { disagree } \\
10=\text { strongly } \\
\text { agree }\end{array}$} \\
\hline $\begin{array}{l}\text { Q4b. Peer review can improve } \\
\text { the quality of the published } \\
\text { paper }\end{array}$ & 7.72 & 1.84 & 7.78 & 1.82 & 7.73 & 1.83 & 7.65 & 1.92 & - & - & - & $N O$ & \\
\hline $\begin{array}{l}\text { Q4c. Peer review can make a } \\
\text { judgement about the novelty of } \\
\text { the manuscript }\end{array}$ & 7.38 & 1.91 & 7.46 & 1.88 & 7.37 & 1.88 & 7.34 & 2.01 & - & - & - & $\begin{array}{c}Y E S \\
(H S S<S T M) \\
\end{array}$ & \\
\hline $\begin{array}{l}\text { Q4d. Peer review can select the } \\
\text { best manuscript for the journal }\end{array}$ & 6.91 & 2.18 & $7.32^{1,2}$ & 2.09 & 6.84 & 2.17 & 6.81 & 2.25 & 25.359 & $<0.001$ & 0.01 & NO & \\
\hline $\begin{array}{l}\text { Q4e. Peer review can } \\
\text { determine the importance of } \\
\text { the findings }\end{array}$ & 7.34 & 1.92 & 7.40 & 1.88 & 7.34 & 1.91 & 7.31 & 1.97 & - & - & - & $\begin{array}{c}Y E S \\
(H S S<S T M) \\
\end{array}$ & \\
\hline $\begin{array}{l}\text { Q4f. Peer review can detect } \\
\text { academic fraud }\end{array}$ & 5.91 & 2.54 & $6.79^{1,2}$ & 2.34 & 5.79 & 2.53 & 5.63 & 2.57 & 89.784 & $<0.001$ & 0.02 & $\begin{array}{c}Y E S \\
(H S S<S T M)\end{array}$ & \\
\hline $\begin{array}{l}\text { Q4g. Peer review can check } \\
\text { the factual accuracy of the } \\
\text { manuscript }\end{array}$ & 6.43 & 2.30 & $6.99^{1,2}$ & 2.17 & 6.34 & 2.31 & 6.27 & 2.32 & 43.809 & $<0.001$ & 0.01 & $\begin{array}{c}Y E S \\
(H S S<S T M)\end{array}$ & \\
\hline $\begin{array}{l}\text { Q4h. Peer review can check for } \\
\text { an appropriate and robust } \\
\text { methodology }\end{array}$ & 7.44 & 1.87 & 7.45 & 1.85 & 7.45 & 1.85 & 7.40 & 1.94 & - & - & - & $N O$ & \\
\hline $\begin{array}{l}\text { Q4i. Peer review can suggest } \\
\text { changes to improve the } \\
\text { readability of the article }\end{array}$ & 7.39 & 1.91 & $7.55^{1,2}$ & 1.93 & 7.39 & 1.89 & 7.27 & 1.95 & 7.570 & 0.001 & 0.002 & $\begin{array}{c}Y E S \\
(H S S<S T M)\end{array}$ & \\
\hline $\begin{array}{l}\text { Q4j. Peer review can highlight } \\
\text { omissions in the content of the } \\
\text { paper }\end{array}$ & 7.30 & 1.84 & 7.39 & 1.89 & 7.28 & 1.81 & 7.29 & 1.90 & - & - & - & $\begin{array}{c}Y E S \\
(S T M<H S S)\end{array}$ & \\
\hline $\begin{array}{l}\text { Q4k. Peer review can } \\
\text { determine whether the article is }\end{array}$ & 7.44 & 2.02 & $7.69^{1,2}$ & 1.97 & 7.39 & 2.03 & 7.38 & 2.04 & 11.641 & $<0.001$ & 0.003 & $N O$ & \\
\hline
\end{tabular}




\begin{tabular}{|c|c|c|c|c|c|c|c|c|c|c|c|c|c|}
\hline \multicolumn{13}{|l|}{$\begin{array}{l}\text { relevant to the journal's aims } \\
\text { and scope }\end{array}$} & \\
\hline $\begin{array}{l}\text { Q41. Peer review can provide } \\
\text { feedback in all circumstances }\end{array}$ & 6.67 & 2.35 & $7.24^{1,2}$ & 2.16 & 6.58 & 2.36 & 6.51 & 2.40 & 43.030 & $<0.001$ & 0.01 & $\begin{array}{c}Y E S \\
(H S S<S T M)\end{array}$ & \\
\hline $\begin{array}{l}\text { Q5a. Peer review indicates that } \\
\text { spelling, grammar and } \\
\text { punctuation mistakes require } \\
\text { correction (suggest sub- } \\
\text { editing) }\end{array}$ & 6.45 & 2.32 & $6.72^{1,2}$ & 2.33 & 6.42 & 2.31 & 6.32 & 2.31 & 10.793 & $<0.001$ & 0.003 & $\begin{array}{c}Y E S \\
(H S S<S T M)\end{array}$ & \multirow{4}{*}{$\begin{array}{l}1=\text { to a very } \\
\text { small extent } \\
10=\text { to a very } \\
\text { great extent }\end{array}$} \\
\hline $\begin{array}{l}\text { Q5b. Peer review corrects } \\
\text { instances of spelling, grammar } \\
\text { and punctuation mistakes } \\
\text { (carry out sub-editing) }\end{array}$ & 5.49 & 2.56 & $6.08^{4}$ & 2.57 & 5.43 & 2.54 & 5.24 & 2.53 & 42.256 & $<0.001$ & 0.01 & $\begin{array}{c}Y E S \\
(H S S<S T M)\end{array}$ & \\
\hline $\begin{array}{l}\text { Q5c. Peer review indicates that } \\
\text { translations require refinement } \\
\text { (suggest language polishing) }\end{array}$ & 6.28 & 2.36 & $6.51^{1,2}$ & 2.32 & 6.25 & 2.37 & 6.19 & 2.32 & 7.560 & 0.001 & 0.002 & $\begin{array}{c}Y E S \\
(H S S<S T M) \\
\end{array}$ & \\
\hline $\begin{array}{l}\text { Q5d. Peer review refines the } \\
\text { translation (carry out language } \\
\text { polishing) }\end{array}$ & 5.23 & 2.55 & $5.88^{1,2}$ & 2.54 & 5.14 & 2.54 & 5.01 & 2.50 & 49.610 & $<0.001$ & 0.02 & $\begin{array}{c}Y E S \\
(H S S<S T M)\end{array}$ & \\
\hline
\end{tabular}

Note: empty cells (-) indicate that no significant difference has been detected.

${ }^{1}$ significant difference between: Author and Reviewer

${ }^{2}$ significant difference between: Author and Editor

${ }^{3}$ significant difference between: Reviewer and Editor

${ }^{4}$ significant difference between: All groups 
Table 3. Ethics of peer review

\begin{tabular}{|c|c|c|c|c|c|c|c|c|c|c|c|c|c|}
\hline \multirow[t]{2}{*}{ Statement } & \multicolumn{2}{|c|}{$\begin{array}{l}\text { Overall } \\
\text { survey } \\
\text { results } \\
\end{array}$} & \multicolumn{2}{|c|}{ Author } & \multicolumn{2}{|c|}{ Reviewer } & \multicolumn{2}{|c|}{ Editor } & \multicolumn{3}{|c|}{$A N O V A$} & \multirow{2}{*}{$\begin{array}{l}\text { Discipline } \\
\text { Differences }\end{array}$} & \multirow[t]{2}{*}{ Scale } \\
\hline & Mean & $\mathrm{sd}$ & Mean & sd & Mean & sd & Mean & $\mathrm{Sd}$ & $F$ & $p$ & $\begin{array}{l}\text { Effect } \\
\text { size }\end{array}$ & & \\
\hline $\begin{array}{l}\text { Q6a. Authors of one } \\
\text { gender are more likely } \\
\text { to be accepted for } \\
\text { publication in a journal } \\
\text { than authors of the } \\
\text { other gender }\end{array}$ & 3.37 & 2.53 & $3.72^{1,2}$ & 2.61 & 3.31 & 2.50 & 3.30 & 2.56 & 13.442 & $<0.001$ & 0.003 & $\begin{array}{c}Y E S \\
(S T M<H S S)\end{array}$ & \\
\hline $\begin{array}{l}\text { Q6b. Authors from } \\
\text { particular regions of } \\
\text { the world are more } \\
\text { likely to be accepted } \\
\text { for publication in a } \\
\text { journal than authors } \\
\text { from other regions of } \\
\text { the world }\end{array}$ & 6.16 & 2.73 & $5.88^{1,2}$ & 2.76 & 6.18 & 2.72 & 6.30 & 2.71 & 8.461 & $<0.001$ & 0.003 & $\begin{array}{c}Y E S \\
(S T M<H S S)\end{array}$ & \\
\hline $\begin{array}{l}\text { Q6c. Authors who hold } \\
\text { a more senior position } \\
\text { in their field are more } \\
\text { likely to be published } \\
\text { in a journal than } \\
\text { authors in a more } \\
\text { junior position }\end{array}$ & 7.05 & 2.51 & $7.07^{2}$ & 2.48 & $7.12^{3}$ & 2.50 & 6.79 & 2.52 & 10.655 & $<0.001$ & 0.003 & $\begin{array}{c}Y E S \\
(S T M<H S S)\end{array}$ & $\begin{array}{c}1=\text { extremely } \\
\text { rare } \\
10=\text { extremely } \\
\text { common }\end{array}$ \\
\hline $\begin{array}{l}\text { Q6d. Reviewers who } \\
\text { are competitors within } \\
\text { the same field delay } \\
\text { their assessment in } \\
\text { order to increase the } \\
\text { likelihood of their own } \\
\text { research being } \\
\text { published first }\end{array}$ & 5.07 & 2.63 & $5.35^{4}$ & 2.53 & 5.08 & 2.63 & 4.80 & 2.67 & 15.355 & $<0.001$ & 0.004 & $\begin{array}{c}Y E S \\
(H S S<S T M)\end{array}$ & \\
\hline $\begin{array}{l}\text { Q6e. Reviewers who } \\
\text { are competitors within } \\
\text { the same field take the }\end{array}$ & 4.96 & 2.55 & 5.02 & 2.52 & 4.96 & 2.56 & 4.92 & 2.57 & - & - & - & $\begin{array}{c}Y E S \\
(H S S<S T M)\end{array}$ & \\
\hline
\end{tabular}




\begin{tabular}{|c|c|c|c|c|c|c|c|c|c|c|c|c|}
\hline $\begin{array}{l}\text { ideas from papers they } \\
\text { are reviewing and use } \\
\text { them in their own } \\
\text { research }\end{array}$ & & & & & & & & & & & & \\
\hline $\begin{array}{l}\text { Q6f. Reviewers give } \\
\text { unduly positive } \\
\text { reviews to authors they } \\
\text { know, in the } \\
\text { knowledge that they } \\
\text { will receive unduly } \\
\text { positive reviews in } \\
\text { return to ensure their } \\
\text { own work is published }\end{array}$ & 5.42 & 2.64 & 5.50 & 2.61 & $5.45^{3}$ & 2.63 & 5.27 & 2.69 & 3.443 & 0.032 & negligent & $\begin{array}{c}Y E S \\
(H S S<S T M)\end{array}$ \\
\hline $\begin{array}{l}\text { Q6g. Reviewers } \\
\text { conduct reviews under } \\
\text { false identities }\end{array}$ & 2.75 & 2.13 & $3.36^{4}$ & 2.35 & 2.68 & 2.06 & 2.47 & 2.06 & 66.978 & $<0.001$ & 0.02 & $\begin{array}{c}Y E S \\
(H S S<S T M)\end{array}$ \\
\hline
\end{tabular}

Note: empty cells (-) indicate that no significant difference has been detected.

${ }^{1}$ significant difference between: Author and Reviewer

${ }^{2}$ significant difference between: Author and Editor

${ }^{3}$ significant difference between: Reviewer and Editor

${ }^{4}$ significant difference between: All groups 


\section{Discussion}

This section reports and discusses the findings relating to the three key objectives of this research, viz, to profile academics' views on the value of the benefits that accrue from, and the ethics of peer review, and to investigate any differences in these three areas arising from role (author, reviewer, editor) or disciplinary (STM or HSS) differences.

First, considering the findings on academics' views on the overall value of peer review, this study affirms findings from earlier studies, that peer review is held in high regard $[1,4,5]$. Respondents confirmed that they regarded peer review as beneficial in improving their article, and that scholarly communication was greatly helped by peer review. Broadly, then, respondents agree that peer review is still king in the digital age [3], despite its limitations.

Secondly, in respect of the specific purpose and benefits of peer review, this study shows that academics are also confident that peer review can check: the factual accuracy of the manuscript; methodology; novelty; relevance to the journal's aims and scope; and, improve readability. On the other hand, respondents are relatively neutral regarding the ability of peer review to detect plagiarism and academic fraud. In this context, there is some consistency between this and earlier studies. For example, Ware et al [1]'s respondents rated making suggestions on presentation, and improving language or readability highly, and Mulligan, Hall and Raphael [4]'s study showed that academics believed that peer review did improve the quality of the published paper, but were very concerned about its contribution to detecting fraud and plagiarism. However, given the differing scopes of prior studies and differing questions it is difficult to make detailed comparison between this study and prior studies.

Finally, this study considered bias and other ethical aspects of the peer review process. This contributes to the social and subjective dimensions of peer review [2]. There is a considerable interest in bias in peer review. Other recent studies have investigated the conceptual integration of multiple biases in peer review [11], and the motivation frames associated with peer review [8], however, these studies do not discuss the extent of specific biases. In contrast, this study examines the demographic variables, gender, region and seniority as sources of bias, and finds that, in general, gender was not seen as a source of bias, but region and seniority were seen as potential sources of bias. In relation to concerns regarding the control of plagiarism, this study suggests that respondents felt that delaying a review, borrowing ideas, and reciprocal support could all be relatively common practices, although there was no expectation that reviewers would adopt false identities.

This study also reports on opinions on the relative potential of different types of peer review to prevent unethical behaviour in the form of giving overly positive reviews of authors they know. Consistent with earlier studies [1,4], respondents had most confidence in double blind peer review. Arguably lower levels of experience with other types of peer review, and issues relating to disclosure of identities [14] means that respondents are cautious in their judgements as to their success. Overall, it would appear that it may be more fruitful to investigate ways of improving double blind peer review, and making it sufficiently robust in an international, digital age, than to develop alternatives. 
Table 4. Ethics and types of peer review

\begin{tabular}{|c|c|c|c|c|c|c|c|c|c|c|c|c|c|}
\hline \multirow[t]{2}{*}{ Statement } & \multicolumn{2}{|c|}{$\begin{array}{l}\text { Overall } \\
\text { survey } \\
\text { results }\end{array}$} & \multicolumn{2}{|c|}{ Author } & \multicolumn{2}{|c|}{ Reviewer } & \multicolumn{2}{|c|}{ Editor } & \multicolumn{3}{|c|}{$A N O V A$} & \multirow{2}{*}{$\begin{array}{c}\text { Discipline } \\
\text { Differences }\end{array}$} & \multirow[t]{2}{*}{ Scale } \\
\hline & Mean & $\mathrm{sd}$ & Mean & $\mathrm{sd}$ & Mean & $\mathrm{sd}$ & Mean & $\mathrm{Sd}$ & $F$ & $p$ & $\begin{array}{l}\text { Effect } \\
\text { size }\end{array}$ & & \\
\hline $\begin{array}{l}\text { Q10a. How capable is } \\
\text { single blind type of peer } \\
\text { review of preventing } \\
\text { reviewers from giving } \\
\text { overly positive reviews } \\
\text { to authors they know in } \\
\text { order to guarantee their } \\
\text { own work is treated } \\
\text { favourably }\end{array}$ & 3.79 & 2.85 & $4.37^{1,2}$ & 2.95 & 3.68 & 2.82 & 3.70 & 2.82 & 29.221 & $<0.001$ & 0.008 & $\begin{array}{c}Y E S \\
(H S S<S T M)\end{array}$ & \multirow{4}{*}{$\begin{array}{c}1=\text { totally } \\
\text { incapable } \\
10=\text { very } \\
\text { capable }\end{array}$} \\
\hline $\begin{array}{l}\text { Q10b. How capable is } \\
\text { double blind type of } \\
\text { peer review of } \\
\text { preventing reviewers } \\
\text { from giving overly } \\
\text { positive reviews to } \\
\text { authors they know in } \\
\text { order to guarantee their } \\
\text { own work is treated } \\
\text { favourably }\end{array}$ & 6.87 & 2.88 & $7.18^{4}$ & 2.76 & 6.90 & 2.87 & 6.56 & 2.95 & 16.287 & $<0.001$ & 0.004 & $N O$ & \\
\hline $\begin{array}{l}\text { Q10c. How capable is } \\
\text { open type of peer } \\
\text { review of preventing } \\
\text { reviewers from giving } \\
\text { overly positive reviews } \\
\text { to authors they know in } \\
\text { order to guarantee their } \\
\text { own work is treated } \\
\text { favourably }\end{array}$ & 4.21 & 2.79 & $4.70^{4}$ & 2.82 & 4.07 & 2.75 & 4.26 & 2.84 & 24.430 & $<0.001$ & 0.007 & $\begin{array}{c}Y E S \\
(H S S<S T M)\end{array}$ & \\
\hline $\begin{array}{l}\text { Q10d. How capable is } \\
\text { open and published type } \\
\text { of peer review of } \\
\text { preventing reviewers }\end{array}$ & 4.97 & 2.89 & $5.31^{1,2}$ & 2.77 & 4.91 & 2.90 & 4.89 & 2.95 & 10.104 & $<0.001$ & 0.003 & $\begin{array}{c}Y E S \\
(H S S<S T M)\end{array}$ & \\
\hline
\end{tabular}




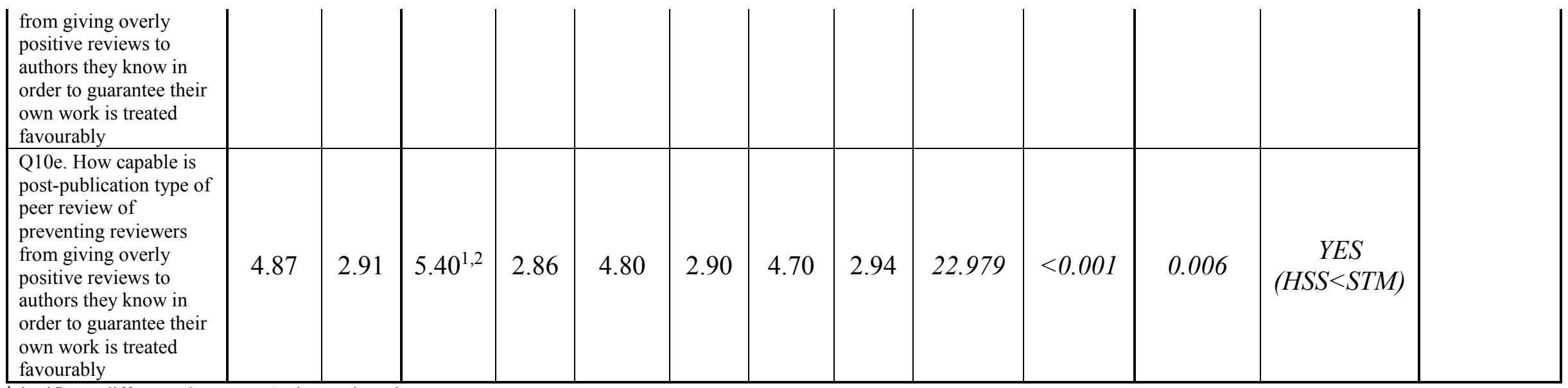

favourably

significant difference between: Author and Reviewer

${ }^{2}$ significant difference between: Author and Editor

${ }^{3}$ significant difference between: Reviewer and Editor

${ }^{4}$ significant difference between: All groups

Table 5. Level of comfort with types of peer review

\begin{tabular}{|c|c|c|c|c|c|c|c|c|c|c|}
\hline & \multicolumn{3}{|c|}{ Authors } & \multicolumn{3}{|c|}{ Reviewers } & \multicolumn{3}{|c|}{ Editors } & Scale \\
\hline & $\mathrm{N}$ & Mean & $\mathrm{sd}$ & $\mathrm{N}$ & Mean & $\mathrm{sd}$ & $\mathrm{N}$ & Mean & $\mathrm{sd}$ & \multirow{6}{*}{$\begin{array}{c}1=\text { very } \\
\text { uncomfortable } \\
10=\text { very } \\
\text { comfortable }\end{array}$} \\
\hline Single blind & 1165 & 4.62 & 2.89 & 4815 & 4.79 & 3.07 & 1558 & 5.11 & 3.25 & \\
\hline Double blind & 1182 & 8.35 & 2.14 & 4875 & 8.64 & 1.93 & 1563 & 8.55 & 2.05 & \\
\hline Open & 1157 & 5.78 & 2.81 & 4795 & 5.38 & 2.98 & 1543 & 5.50 & 3.11 & \\
\hline Open and published & 1163 & 5.45 & 2.89 & 4800 & 4.99 & 3.02 & 1549 & 4.99 & 3.14 & \\
\hline Post-publication & 1160 & 5.23 & 2.90 & 4784 & 4.77 & 2.96 & 1542 & 4.85 & 3.13 & \\
\hline
\end{tabular}


This study also offers novel insights through comparing respondents in different disciplines and with different roles. Amongst previous studies, only Mulligan et al. [4] report on disciplinary differences in attitudes to peer review. Their summary on satisfaction with peer review, and the contribution of peer review to scholarly communication in STM subjects, showed some small variations for specific disciplines, but broad consensus regarding the value of peer review. In this study, as regards the overall value of peer review, there are no differences on the basis of discipline. However, in respect of the statements on the more specific benefits and purpose of peer view, there were significant disciplinary differences on many of the statements. For some statements, this hints at the possibility of different underlying practices between STM and HSS disciplines in areas such as novelty judgments, checking factual accuracy and improving readability. Such differences in disciplinary attitudes to peer review have also been identified in other recent studies [7]. This study also explored disciplinary differences in respect of the ethics of and bias in peer review. There was a significant disciplinary difference in the expected impact of gender, geography and seniority on the outcome of the review process, and on dubious practices such as delaying a review, borrowing ideas, reciprocal support, and using false identities.

The other central contribution of this study relates to any differences in attitude on the basis of role. Earlier studies have either focussed on reviewers' or academics' attitudes [1,3,8] or studied two of the three groups of authors, reviewers and editors [4 - authors and reviewers; 2 - editors and reviewers]. This study makes a comparison across all three of these groups, thereby generating insights across the full spectrum of experience with the peer review process. There were no significant differences in attitudes between the three groups with respect their overall view of the importance of peer review. However, when asked in more detail about the specific value and benefits of peer review, authors are in every instance more positive than reviewers, and, in turn, reviewers are more positive than editors, although not all of these differences are statistically significant. This suggests that those with a more extensive and multi-dimensional experience of peer review have greater reservations regarding its benefits, in relation, for instance to its ability to detect plagiarism, improve the quality of the published paper, ad select the best manuscript for the journal. In terms of the ethics of peer review, authors were a little more inclined to think that there was a gender bias, than reviewers or editors, and in relation to seniority, editors viewed this as less common than did authors and reviewers, and editors were more likely to see region as a source of bias than authors or reviewers. Finally, considering fraudulent practices, viz, delaying a review, borrowing ideas, reciprocal support and using false identities, there is evidence of some differences between groups. Editors thought both false identities and deliberate delays in assessment were much less likely to happen, than did reviewers and authors, but there was no significant difference of opinion on whether borrowing ideas. Finally, when considering the potential for favouritism in the context of different types of peer review, in almost all instances, authors were more confident than reviewers and reviewers more confident than editors the specific type of peer review would prevent this. 


\section{Conclusion and recommendations}

\subsection{Summary}

This article draws on data from a major international survey, based on the database of authors and reviewers of a major publisher, Taylor \& Francis. It offers insights into academics' views regarding the value, benefits and ethical aspects of peer review in the context of scholarly communication. It demonstrates that peer review is still highly valued, but that there are variations in the level of confidence in peer review to achieve some of its key purposes, and views on the extent to which it can be ensured that all practices are ethical. In addition to providing a general profile, analyses have been performed to explore any differences on the basis of the status of the respondents (author, author and reviewer, author, reviewer and editor, and on the basis of the two major disciplinary groups, STM and HSS. These analyses do show some significant differences in views between respondents with different status, with views varying more between the group Author and the group Reviewer, than between the groups Reviewer and Editor. In addition, there is some evidence of disciplinary differences in views on both the benefit of peer review and on its ethical dimensions.

\subsection{Recommendations for practice and further research}

Given the increasing inter-disciplinarity and internationalisation of scholarly communications processes, and the growth of open access publishing, both through established scholarly journals, and more recently in the form of open access interdisciplinary mega-journals, these are challenging times for peer review. Various models of peer review have been proposed, but authors are demonstrating their preference for the most established model, double-blind peer review, and there is little evidence as yet to suggest that other approaches will increase confidence in peer review. Indeed, it is of some concern that those who have greater experience with peer review (reviewers and editors) have less confidence in its ability to deliver on both benefits and ethics, than those with less experience (authors). Hence, there is an ongoing need for those responsible for the peer review processes to seek out and implement approaches that ensure peer review continues to be beneficial to the scholarly community.

In addition, whilst this study has generated a rich range of insights into views on the value, benefits and ethical aspects of peer review in scholarly communication, there is considerable scope for further research. In recognition of the importance of peer review, there have been three other significant international surveys of researchers on this topic in recent years, which all offer interesting insights, but there is considerably more work to do in understanding different responses from different disciplinary communities. For example, this study shows significant disciplinary differences, between HSS and STM; these need further exploration. In addition, it would be useful to further probe the views of people with different roles in the peer review process, including conducting more qualitative studies in order to generate insights into attitudes towards the peer review process, with a view to, for instance, developing theoretical models that influence willingness to, and thoroughness of review. Finally, another limitation of most of the research to date, whether it is the qualitative or quantitative tradition is that it is descriptive. As such, it is about theory development, and engages to only a limited extent in 
theory testing, which might involve the identification of key variables associated with the peer review process, and the relationships between them. For example, one key arena in which this might be taken forward in in relation to the impact of aspects of the peer review process on trust in the scholarly communication, and the related arena of the control of plagiarism.

Acknowledgements: The authors are grateful to Taylor \& Francis for access to the data generated from a survey designed and conducted by a team of their staff, including Will Frass, Senior Research Executive, Elaine Devine, Communications Manager (Author Relation), Jo Cross, Head of Research and Business Intelligence, and Victoria Gardner, Open Access publisher.

\section{References}

[1]Ware M. Peer review: benefits, perceptions and alternatives. Publishing Research Consortium, London (PRC Summary Papers 4), 2008

[2] Lipworth WL, Kerridge IH, Carter SM et al. Journal peer review in context: A qualitative study of the social and subjective dimensions of manuscript review in biomedical publishing. Social Science \& Medicine 2011; 72(7): 1056-1063.

[3] Nicholas D, Watkinson A, Jamali HR et al. Peer review: still king in the digital age. Learned Publishing 2015; 28(1): 15-21.

[4] Mulligan A, Hall L and Raphael, E. Peer review in a changing world: An international study measuring the attitudes of researchers. Journal of the American Society for Information Science and Technology 2013; 64(1): 132-161.

[5] Nicholas D, Watkinson A, Volentine $\mathrm{R}$ et al. Trust and authority in scholarly communications in the light of the digital transition: Setting the scene for a major study. Learned Publishing 2014; 27(2): 121-134.

[6] Tenopir C, Levine K, Allard S et al. Trustworthiness and authority of scholarly information in a digital age: Results of an international questionnaire. Journal of the Association for Information Science and Technology (2015); 67(10): 2344-2361.

[7] Rowley J, Johnson F, Sbaffi L et al. Academics' behaviours and attitudes towards open access publishing in scholarly journals. Journal of the Association for Information Science and Technology 2017; Early View, DOI: 10.1002/asi.23710.

[8[ Zaharie MA and Osoian CL. Peer review motivation frames: A qualitative approach. European Management Journal 2016; 34(1): 69-79.

[9] Siler K, Lee K. and Bero L. Measuring the effectiveness of scientific gate keeping. Proceedings of the National Academy of Sciences 2015; 112(2): 360-365.

[10] Lee CJ, Sugimoto CR, Zhang G. and Cronin B. Bias in peer review. Journal of the American Society for Information Science and Technology 2013; 64(1): 2-17.

[11] Zhao YW, Chi C-H and Van den Heuve W-J. Imperfect referees: reducing the impact of multiple biases in peer review. Journal of the American Society for Information Science and Technology 2015; 66(11): 2340-2356.

[12] Jamali HR, Nicholas D, Watkinson A et al. How scholars implement trust in their reading, citing and publishing activities. Library \& Information Science Research 2014; 36(3-4): 192-202. 
[13] Garcia JA, Rodrigues-Sanchez R and Fdez-Valdivia J. Bias and effort in peer review. Journal of the American Society for Information Science and Technology 2015; 66(10): 2020-2030.

[14] Nobarany S and Booth KS. Understanding and supporting anonymity policies in peer review. Journal of the Association for Information Science and Technology 2016; 68(4): 957-971. 
Appendix 1. Key previous studies on peer review

\begin{tabular}{|c|c|c|c|c|c|c|}
\hline Author(s) & Title & Date & $\begin{array}{c}\text { Geographical } \\
\text { coverage }\end{array}$ & Population & Topics & $\begin{array}{c}\text { Research } \\
\text { method }\end{array}$ \\
\hline Ware [1] & $\begin{array}{l}\text { Peer review: benefits, } \\
\text { perceptions, } \\
\text { alternatives }\end{array}$ & 2008 & Global & $\begin{array}{l}3040 \\
\text { academics }\end{array}$ & $\begin{array}{l}\text { Types and durations of peer review, } \\
\text { reviewers' perspectives and editors' role, } \\
\text { benefits of peer review }\end{array}$ & Survey \\
\hline $\begin{array}{l}\text { Lipworth et al } \\
\text { [2] }\end{array}$ & $\begin{array}{l}\text { Journal peer review in } \\
\text { context: a qualitative } \\
\text { study of the social and } \\
\text { subjective dimensions } \\
\text { of manuscript review in } \\
\text { biomedical publishing }\end{array}$ & 2011 & $\begin{array}{l}\text { UK, USA, } \\
\text { Australia }\end{array}$ & $\begin{array}{l}35 \text { editors and } \\
\text { reviewers in } \\
\text { biomedicine }\end{array}$ & $\begin{array}{l}\text { Motivations, power relations, authority, } \\
\text { moral responsibility, prejudice and } \\
\text { intuition }\end{array}$ & Interviews \\
\hline $\begin{array}{l}\text { Mulligan et al } \\
{[4]}\end{array}$ & $\begin{array}{l}\text { Peer review in a } \\
\text { changing world: an } \\
\text { initial study measuring } \\
\text { the attitudes of } \\
\text { researchers }\end{array}$ & 2013 & Global & $\begin{array}{l}4000 \\
\text { researchers }\end{array}$ & $\begin{array}{l}\text { Attitudes towards peer review, including } \\
\text { satisfaction levels, importance and } \\
\text { sustainability the purpose of peer review } \\
\text { and the effectiveness of different types of } \\
\text { peer review. Some analysis was } \\
\text { conducted on a disciplinary basis. Also } \\
\text { reported on authors' experience of peer } \\
\text { review, and their motivations }\end{array}$ & Survey \\
\hline Lee et al. [10] & Bias in peer review & 2013 & $\mathrm{~N} / \mathrm{A}$ & N/A & $\begin{array}{l}\text { Reviews types of bias (author } \\
\text { characteristics, reviewer characteristics, } \\
\text { content), discusses the effect of review } \\
\text { type }\end{array}$ & Conceptual \\
\hline
\end{tabular}




\begin{tabular}{|c|c|c|c|c|c|c|}
\hline $\begin{array}{l}\text { Nicholas et al. } \\
\text { [3] }\end{array}$ & $\begin{array}{l}\text { Peer review: still king } \\
\text { in the digital age }\end{array}$ & 2015 & Global & $\begin{array}{l}4000 \\
\text { researchers }\end{array}$ & $\begin{array}{l}\text { Continued importance of peer review, } \\
\text { merits and criticisms of peer review, link } \\
\text { between peer review and trust }\end{array}$ & Survey \\
\hline Siler et al. [9] & $\begin{array}{l}\text { Measuring the } \\
\text { effectiveness of } \\
\text { scientific gatekeeping }\end{array}$ & 2015 & $\begin{array}{l}\text { Three elite } \\
\text { medical } \\
\text { journals }\end{array}$ & $\begin{array}{l}1008 \\
\text { submitted } \\
\text { manuscripts }\end{array}$ & $\begin{array}{l}\text { Editors and reviewers generally made } \\
\text { good decisions, but some manuscripts } \\
\text { that were eventually published elsewhere } \\
\text { attracted high levels of citation }\end{array}$ & $\begin{array}{l}\text { Desk } \\
\text { research }\end{array}$ \\
\hline Zhao et al. [11] & $\begin{array}{l}\text { Imperfect referees: } \\
\text { reducing the impact of } \\
\text { multiple biases in peer } \\
\text { review }\end{array}$ & 2015 & $\begin{array}{l}\text { Two } \\
\text { international } \\
\text { conferences }\end{array}$ & $\begin{array}{l}\text { Programme } \\
\text { chair reviews }\end{array}$ & $\begin{array}{l}\text { Compares the impact of two types of bias } \\
\text { on review outcomes: static reviewer } \\
\text { profiles and dynamic behavioural context. } \\
\text { Reliability of referees' judgments varies } \\
\text { according to their static profiles and is } \\
\text { contingent upon the temporal interval } \\
\text { between two consecutive reviews }\end{array}$ & $\begin{array}{l}\text { Analysis of } \\
\text { review } \\
\text { judgements }\end{array}$ \\
\hline
\end{tabular}

